\title{
ARTYKUŁY
}

\author{
Maria Magdalena Biernacka \\ Warszawa, Polska \\ niezależny badacz \\ stokrotka@upcpoczta.pl
}

Profesor Barbarze Bieńkowskiej-

mojej Mistrzyni, Nauczycielce i Przyjaciółce - ofiarowuje

\section{Kartka z dziejów nauczania bibliologii. Wokół notatek do wykładów Józefa Muczkowskiego na Uniwersytecie Jagiellońskim w latach 1837-1858}

\section{Notes to the lectures of Józef Muczkowski at the Jagiellonian University in the years 1837-1858}

\begin{abstract}
The manuscript legacy of Józef Muczkowski, preserved in the Jagiellonian Library, includes extensive notes and materials to the lectures on bibliography, defined as the book science in the broadest sense. Muczkowski had been giving these lectures for 21 years, in the period 1837-1858. The article characterizes generally physical form, formal and content aspects of these manuscripts. The author notices a variety of their form and inconsistency of elaboration, successive completion and updating, or even the existence of several versions of particular subjects. The article presents also in extenso three lists of examine questions prepared by the lecturer to verify students' knowledge of book science. As such, they have not been known to the book scientists so far, and therefore they are unique and still valid. Analysis of sources to these lectures revealed that, besides works of Joachim Lelewel, Muczkowski referred also to the texts of outstanding foreign humanists, experts in library science.
\end{abstract}

Key words: Józef Muczkowski (1795-1858) - bibliography - book science - history of education Jagiellonian University - Cracow - 1837-1858.

Słowa kluczowe: Józef Muczkowski (1795-1858), bibliografia, bibliologia, historia nauczania, Uniwersytet Jagielloński, Kraków - 1837-1858.

„Z Badań nad Książką i Księgozbiorami Historycznymi” - Udział zagranicznych recenzentów w ocenie publikacji; Stworzenie anglojęzycznej wersji wydawniczej publikacji; Digitalizacja tomów archiwalnych rocznika w celu zapewnienia otwartego dostępu do nich przez Internet oraz wdrożenie i utrzymanie cyfrowej platformy redakcyjnej - zadanie finansowane w ramach umowy nr 653/P-DUN/2019 ze środków Ministra Nauki i Szkolnictwa Wyższego przeznaczonych na działalność upowszechniającą naukę. 


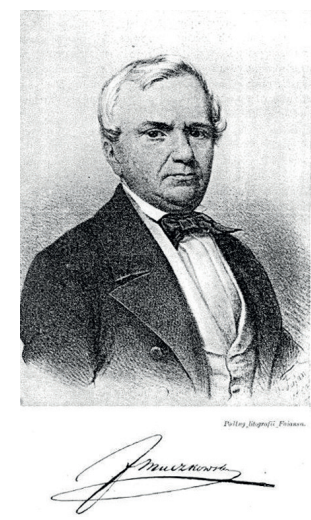

Fot.1. Józef Muczkowski w 1850 r. Źródło: reprodukcja wizerunku na podstawie litografii Maksymiliana Fajansa, [w:] Album biograficzne zastużonych Polaków i Polek wieku XIX. T. 2, Warszawa 1903, s. 414

W lipcu 2020 r. miną 162 lata od śmierci Józefa Muczkowskiego - wieloletniego dyrektora Biblioteki Jagiellońskiej w Krakowie i profesora bibliografii oraz nauk pomocniczych historii Uniwersytetu Jagiellońskiego. J. Muczkowski (pierwotne nazwisko Muciek) urodził się 17 III 1795 r. w miejscowości Maszki (obecnie w gminie Wojciechów, w powiecie i województwie lubelskim), w ubogiej rodzinie chłopskiej. Zmarł 31 VII 1858 r. w Krakowie na apopleksję, w trakcie prowadzenia badań w katedrze na Wawelu (w kaplicy Świętokrzyskiej) do swojej - okazało się, że ostatniej - pracy. Została ona opublikowana pośmiertnie pt. Dwie kaplice Jagiellońskie w Krakowie oraz najdawniejsze wizerunki Jagietly i Jadwigi ${ }^{1}$, a także jako osobne wydanie pt. Dwie kaplice Jagiellońskie w katedrze krakowskiej (Kraków 1859).

J. Muczkowski jest postacią niesłusznie zapomnianą. Był zasłużonym historykiem i filologiem, archiwistą i wydawcą źródeł historycznych, autorem prac do dziejów UJ i BJ, bibliografem, bibliotekarzem i profesorem uniwersyteckim. Był także cenionym historykiem kultury, bibliologiem propagującym kulturę książki, uniwersyteckim wychowawcą wielu wybitnych pracowników książki - bibliografów, bibliotekarzy, archiwistów, księgarzy i wydawców, bibliofilów i zbieraczy pamiątek narodowych, literatów i uczonych. Jest on jednym z wybitnych przedstawicieli krakowskiej szkoły bibliologicznej i bibliograficznej w XIX w. Był wychowankiem, a z czasem bliskim współpracownikiem i w latach 1837-1858 następcą Jerzego Samuela Bandtkiego (1768-1835) na obu zajmowanych przez niego stanowiskach w UJ, jak już wspomniano - dyrektora BJ i profesora bibliografii. Bandtkie - historyk, badacz dziejów Śląska, językoznawca, bibliotekarz, historyk drukarstwa i teoretyk bibliografii był jednym z pierwszych uniwersyteckich wykładowców tej dyscypliny w Polsce. Prowadził zajęcia przez 23 lata, od roku akademickiego 1811/12 do 1833/34.

Antoni Zygmunt Helcel (1808-1870) słuchał wykładów Bandtkiego w roku akademickim 1827/28. Został historykiem prawa polskiego, wydawcą źródeł, politykiem i publicystą, od $1850 \mathrm{r}$. był profesorem zwyczajnym na Wydziale Prawa UJ. Ten wierny uczeń scharakteryzował swojego profesora i jego wykłady bibliografii, pisząc we wspomnieniu pośmiertnym poświęconym Bandtkiemu m.in.:

\footnotetext{
1 „Rocznik Towarzystwa Naukowego Krakowskiego” 1858, t. 25.
} 
Uchwycił on [Bandtkie] przedmiot Bibliografii najmniej u nas opracowany i zajmował się nim z tem [sic!] większą ochotą, że widział, jak ta gałąź lekce ważoną [sic!] była, i jak o niej między miłośnikami nawet nauk, najfałszywsze pojęcia miano. Naukę tę znano tylko z jej mechanicznej niejako strony, jako nudną wiadomość o formacie, roku wydania i drukarzu książki. Nie widziano, jak sama nauka ta jest czemś [sic!] nierównie więcej, niż jej nazwa wskazuje; nie wnikano w to, że w martwej i butwiejącej księdze, że w maluchnej czcionce drukarskiej, że w jednej napisanej literze jest ukryty promień życia umysłowego, jakby duch zaklęty w pęta materii; że więc wiadomość o zabytkach w piśmie i druku złożonych, odnosząca się tak do względu technicznego, jako też i do oceniania wartości dzieł wewnętrznej i zewnętrznej, jest połączona ściśle z dziejami oświaty. [...] Wykład jego [Bandtkiego] był jakby wspólnem [sic!] ćwiczeniem się mistrza z uczniami; a ta jego rześka nauczycielska ochota, i bez wszelkiej przesady udzielane skarby najwytrawniejszej uczoności, przeplatanie rzeczy nawet suchych, często najbardziej zajmującemi [sic!] wiadomościami historycznemi [sic!], wszystko to ściągało do szkoły jego uczniów gorliwością się w naukach odznaczających. Kto by pragnął poznać owoce nauczycielskich prac BANDTKIEGO, ten niechaj spojźrzy [sic!] na poczet znakomitszych w nowej literaturze imion. Zaszczytnie znani na polu naukowem [sic!] mężowie: JAN WINCENTY BANDTKIE, WACŁ[AW] ALEKS[ANDER] MACIEJOWSKI, [JAN] KAJETAN TROJAŃSKI, JÓZEF MUCZKOWSKI, szczycą się tem [sic!] otwarcie, iż w swych postępach główniej jego za mistrza i pomocnika mieli². Uzupełniając tę informację, dodam, że brat Jerzego Samuela, Jan Wincenty Bandtkie (1783-1846) był historykiem prawa, profesorem Szkoły Prawa i Administracji w Warszawie, następnie Królewskiego Uniwersytetu Warszawskiego, edytorem i leksykografem. Wacław Aleksander Maciejowski (1793-1883), historyk kultury, prawa i literatury, uczęszczał na wykłady Bandtkiego w roku akademickim 1812/1813, a Jan Kajetan Trojański (1797 lub 1796-1850), filolog klasyczny, leksykograf, profesor i rektor UJ, prezes Towarzystwa Naukowego Krakowskiego był studentem Bandtkiego w roku akademickim 1813/14.

J. Muczkowski słuchał wykładów Bandtkiego dwukrotnie: jako jeden z 22 słuchaczy, będąc w 1812/13 r. studentem II roku Wydziału Filozoficznego UJ i ponownie, jako jeden z dziewięciu słuchaczy, w 1815/16 r. ${ }^{3}$ Okres od stycznia 1813 r. do marca 1815 r. był czasem, gdy Muczkowski przerwawszy studia, wstapił do armii Księstwa Warszawskiego i jako podporucznik pułku ułanów gwardii Napoleona walczył w Niemczech i Francji. Zrezygnowawszy z dalszej służby wojskowej, wrócił do Krakowa, aby kontynuować studia, które ukończył w 1817 r.

2 Helcel A.Z., Jerzy Samuel Bandtkie w stosunku do spoteczności i literatury polskiej. Przyczynek naukowy do dziejów literatury ojczystej, Kraków 1836, s. 32, 40-41. Na opinię A.Z. Helcla o Bandtkiem powoływał się uznany krytyk i historyk literatury polskiej Piotr Chmielowski (18481904) w biogramie uczonego umieszczonym w Albumie biograficznym zastużonych Polaków i Polek wieku XIX. T. 1, Warszawa 1901, s. 416. Słowa A.Z. Helcla zacytował również Karol Lewicki w artykule Jerzy Samuel Bandtkie, profesor bibliografii Uniwersytetu Jagiellońskiego, 1811-1835, „Roczniki Biblioteczne” 1972, R. 16, z. 1/2, s. 126-127.

3 K. Lewicki, Jerzy Samuel Bandtkie..., s. 133-134. 
Poglądy i działalność naukowa, zawodowa i dydaktyczna J. Muczkowskiego - ucznia, współpracownika i następcy J.S. Bandtkiego, a także (w roku akademickim 1844/45) nauczyciela bibliografii Karola Estreichera starszego (1827-1908), który prowadził wykłady tej dyscypliny w warszawskiej Szkole Głównej w latach 1865-1868, wyraźnie wskazują na trwałe oddziaływanie o charakterze mistrz - uczeń: Bandtkie - Muczkowski - Estreicher st. Rozpoczynając 22 III 1865 r. wykłady bibliografii w Warszawie, Estreicher st. wspomniał bowiem: „Rękopism z wykładów J. Bandtkiego posiadam. Rękopisa wykładów prof. Muczkowskiego i [Pawła] Jarkowskiego [1781-1845] zachowane są u familii tychże"4.

Analogie merytoryczne wykładów szeroko pojmowanej bibliografii jako nauki w ujęciu Bandtkiego, Muczkowskiego i Estreichera st. są bardzo wyraźne. Oczywiście, istniejące różnice w uwzględnianiu i rozbudowywaniu lub pomijaniu na wykładach bibliografii niektórych dyscyplin wchodzących $w$ jej skład, wynikały z indywidualnych zainteresowań naukowych trzech profesorów. Cechą wspólną ich wykładów był również pragmatyzm. Były one uniwersytecką nauką praktycznego poznawania rozległej wiedzy o piśmie, książce i bibliotece, przydatną dla różnorodnych i szerokich kręgów przyszłych pracowników książki. Stosowanie poglądowej metody nauczania ułatwiało wykładowcom realizację tych celów, a jej dydaktyczne walory były bezsporne. Najdoskonalszą zaś pomocą metodyczną było pokazywanie znajdujących się w zbiorach bibliotecznych (BJ w Krakowie i Biblioteki Głównej w Warszawie) egzemplarzy. Wspólną, charakterystyczną cechą wykładów Bandtkiego, Muczkowskiego i Estreichera st. była również, towarzysząca ich zajęciom, atmosfera patriotyzmu i wpajanie studentom kultu dla narodowej przeszłości. Profesorowie ujmowali bibliografię w ścisłym związku z życiem kulturalnym, z panującymi w kraju stosunkami politycznymi, gospodarczymi i społecznymi.

Jako dowód trwałego oddziaływania mistrza na ucznia warto przypomnieć trzy charakterystyki wykładów Muczkowskiego, podane przez K. Estreichera st. We wspomnieniu o swoim profesorze, opublikowanym w 1858 r. $^{5}$, napisał między innymi:

Był to miły, podtatusiały, ale czerstwy, rumiany, piękną siwizną odznaczający się, nader prawego i otwartego charakteru profesor. Kochaliśmy go za jego szczerość, gdy przyszło prawdę uczniowi wypowiedzieć, za jego zachęcanie każdego do miłowania literatury i garnienia się do nauk. Wykład jego bibliografii mimo, że się cokolwieczek niepłynnie wysławiał, był bardzo interesującym swą treścią, jako też doborem przykładów, które uczniom z okazywanych dzieł zeszłowiecznych odczytywał ${ }^{6}$.

$4 \quad$ K. Estreicher [st.], O bibliografii. Przemówienie w Szkole Głównej w Warszawie, miane dnia 22 marca 1865 r., przy rozpoczęciu wykładu tej umiejętności, Warszawa 1865, s. 23.

5 Au.K. [K. Estreicher st.], Józef Muczkowski, „Dziennik Literacki” 1858, nr 97, s. 790-792.

6 Tamże, s.791. 
Cztery lata później, osobiście zainteresowany obsadą personalną powstającej w Warszawie Szkoły Głównej, wspominał swoich dwóch profesorów, pisząc 26 VI 1862 r. ze Lwowa do Kazimierza Władysława Wójcickiego (1807-1879):

Ciekawy jestem, kto będzie wykładał literaturę powszechną, kto wyłoży bibliografię wraz z sfragistyką, heraldyką i numizmatyką. W Uniwersytecie Jagiell[ońskim] słuchałem pierwszego przedmiotu pod M[ichałem] Wiszniewskim [1794-1865], drugich pod Muczkowskim. Obadwaj byli w swoim rodzaju znakomici. Muczkowski lubo zająkiwał się, tak nam umiał ożywić naukę bibliografii, tyle w nią wlać ognia, że każden rad zapalał się do każdego pergaminu, starej książki i monety. Jemu może najwięcej zawdzięczam zamiłowanie bibliografii, bo od czasu jego prelekcji szperam po książkach i papierach ${ }^{7}$.

Najobszerniej scharakteryzował Estreicher st. Muczkowskiego jako człowieka, uczonego, bibliotekarza i profesora bibliografii w biogramie, który ukazał się w 1903 r. a więc po prawie 60 latach, od czasu gdy był jego studentem i zarazem - po prawie 40 latach, kiedy sam również wykładał ten przedmiot w Szkole Głównej w Warszawie ${ }^{8}$. Napisał między innymi:

Muczkowski, będąc bibliotekarzem objął także wykład bibliografii, jako przedmiotu nadobowiązkowego. Katedra była potrzebną, bo przysposabiała przyszłych urzędników biblioteki i wyrabiała przyszłych historyków. Uczono tu prócz znawstwa ksiąg, także paleografii, numizmatyki, heraldyki, które to przedmioty znał Muczkowski gruntownie. Doskonały łacinnik, przerabiał z uczniami dyplomata, a przy tej okazji lekcja przybierała charakter wykładu literatury i historii polskiej, których nie uczono ani w gimnazjum ani w uniwersytecie. W wąskiej izbie, przy długim stole, siedział profesor obłożony książkami, trzymający w ręku karteczki zapisane. Uczniowie obsiadywali stół, a dwaj posługacze stali gotowi na rozkazy. Muczkowski nie był wymowny, a więc przy pamięciowym wykładzie z kartek zająkiwał się, jak gdyby mu wyrazów brakło, tylko głową poruszał i ręką wstrząsał, zniecierpliwiony. Od czasu do czasu pytał ucznia o datę zgonu króla, lub szczegół głośnej batalii, a biada jeżeli nie wiedział - było strofowanie, że przeszłość jest własnością naszej pamięci. Prawda, że podczas każdej lekcji grzmiał jego głos z przezwiskami na posługaczy, dostał się też niejednemu uczniowi ostry epitet, jeżeli nie znał poety lub historyka, a lubo to nie miało związku z bibliografią, jednakowoż młodzież wybaczała mu ton ostry, opryskliwy, bo wiedziała, że to wypływało z wielkiej miłości do tego wszystkiego co przeszło. Ceniono jego charakter czysty jako łza i otwartość szorstką, której nie ukrywał wobec najsilniejszych potentatów. Nie uginał się nigdy9.

Estreicher st. silnie podkreślał charakterystyczne cechy wykładów Muczkowskiego - stosowanie metody poglądowej i patriotyzm, wpajanie kultu dla

7 K. Estreicher [st.], Z listów. Cz. 2, [wyd.] J. Grzybowska, „Biuletyn Biblioteki Jagiellońskiej” 1961, R. 13, nr 1, s. 28.

$8 \quad$ K. Estreicher [st.], Józef Muczkowski, *1795†1858, [w:] Album biograficzne zastużonych Polaków i Polek wieku XIX. T. 2, Warszawa 1903, s. 414-418.

9 Album biograficzne zastużonych Polaków..., s. 417. 
narodowej przeszłości. Pamiętał o nich z własnego studenckiego doświadczenia i bardzo je cenił. W całej zaś rozciągłości przejął je 20 lat później we własnej działalności dydaktycznej. 10 XII 1864 r., jeszcze przed rozpoczęciem wykładów w Szkole Głównej w Warszawie, zapowiadał w Memoriale w obronie katedry bibliografii, że będzie szeroko stosował metodę poglądową:

każdej lekcji towarzyszy praktyczny wykład na książkach i wzorach, ułatwia to niezmiernie młodzieży orientowanie się w źródłach naukowych i zachęca do pracy książkowej ${ }^{10}$.

A bezpośrednia relacja uznanego encyklopedysty Józefa Krzywickiego (1838-1908), współpracującego z Encyklopedia powszechna (28 t., 1859-1868) Samuela Orgelbranda (1810-1868) i Stownikiem geograficznym Królestwa Polskiego i innych krajów słowiańskich (15 t., 1880-1914) potwierdza, że Estreicher st. zachował ciągłość w przekazywaniu wiedzy bibliologicznej metodami swoich mistrzów, a także kultywował atmosferę patriotyzmu towarzyszącą ich wykładom. J. Krzywicki, będąc studentem Szkoły Głównej w Warszawie, słuchał jego wykładów w latach akademickich 1864/65-1866/67. Zajęcia z bibliografii utrwaliły się w jego pamięci jako interesujące i barwne wykłady z dziejów polskiej kultury. Jego wspomnienia pt. Katedra bibliografii. Profesor Karol Estreicher ukazały się drukiem w 1900 r. - po 35 latach od tamtych, studenckich czasów ${ }^{11}$. J. Krzywicki zaznaczył między innymi:

Wielka zasługa Estreichera [st.] polega i na tem [sic!], że nie wkraczając ani razu w dziedzinę historii literatury, oceniał zewnętrznie tylko jej pomniki, a wytwarzanie się, postęp i rozwój ich śledząc, uchronił się od drugiej ostateczności, od suchego katalogowania i regestrowania faktów. Owszem w tych formach zewnętrznych umiał wyśledzić cywilizacyjne ich znaczenie, umiał je wskazać i przedmiot suchy na pozór uczynił zajmującym i żywotnym ${ }^{12}$. Krzywicki wspominał też o różnorodności materiałów oglądowych, przedstawianych na wykładach:

Przy pomocy zbioru facsimiliów ksylograficznych przeszedł on dzieje i rodzaje tego kunsztu [sztuki drukarskiej], używany materiał i rozpatrzył miedziorytnictwo książkowe. Następnie położył nacisk na jak największe obznajmienie [sic!] się z inkunabułami, które bądź w bibliotece miejscowej się znajdowały, bądź je w podobiznach przedstawiał: przy tem [sic!] sformułował tablice inkunabułów z XV w. Potem przeszedł historię drukarstwa u wszystkich ludów całego świata, najszczegółowiej zajmując się drukarstwem polskim. Uplastycznienie wykładów przez okazywanie druków, jakie biblioteka posiadała, niezmiernie się do zapamiętania cech wyróżniających przyczyniło ${ }^{13}$.

10 K. Estreicher [st.], Memoriat w obronie katedry bibliografii, wyd. K.Ś. [Ksawery Świerkowski], „Przegląd Biblioteczny” 1928, R. 2, z. 1, s. 51.

11 J. Krzywicki, Katedra bibliografii. Profesor Karol Estreicher, [w:] Szkoła Główna Warszawska (1862-1869). T. 1: Wydziat Filologiczno-Historyczny, Kraków 1900, s. 251-258.

12 Tamże, s. 257.

13 Tamże, s. 256. 
Zwracał również uwagę na atmosferę patriotyzmu, towarzyszącą zajęciom z bibliografii:

Estreicher [st.] kładł wielki nacisk na rzeczy polskie i, podnosząc do należytej wysokości obraz oświaty naszej, szczególniej w wiekach XV i XVI, obudzał w słuchaczach zamiłowanie do rzeczy swojskich $\mathrm{i}$ w duszy niejednego z młodzieży budził postanowienie zajęcia się pomnikami przeszłości ${ }^{14}$.

Mniej znaną i wybitną postacią świata książki niż K. Estreicher st. był jego rówieśnik i także słuchacz wykładów Muczkowskiego - Józef Łoziński (18271897), bibliotekarz rodowej Biblioteki Dzieduszyckich w Poturzycy i Lwowie. Napisany przez Wacława Olszewicza (1888-1974) w 1944 r. we Lwowie interesujący artykuł o Łozińskim, zawierający fragmenty pozostającego w rękopisie jego pamiętnika pt. Wspomnienia z życia swego opowiedziat dzieciom i wnukom swoim Józef Łoziński w listopadzie roku 1892, ukazał się w 1959 r. w „Rocznikach Bibliotecznych”15. W latach akademickich 1850/51-1853/54 Łoziński studiował filologię klasyczną i niemiecką na UJ, praktykując równocześnie w BJ pod kierunkiem Muczkowskiego. Zasługują na przytoczenie, pełne sentymentu, słowa uznania i wdzięczności, w jakich po 40 latach wspominał Łoziński swojego profesora i opiekuna:

Przybywszy do Krakowa wpisałem się na listę uczniów Uniwersytetu Wydziału Filozoficznego i rozpocząłem praktykę w Bibliotece Jagiellońskiej, będącej naówczas pod sterem uczonego i przezacnego Józefa Muczkowskiego, autora wielu dzieł cennych i prawdziwego przyjaciela młodzieży. W ciągu lat czterech pobytu mego w Krakowie słuchałem wykładów [Józefa] Kremera [1806-1875], [Wincentego] Pola [1807-1872], [Franciszka Tomasza] Bratranka [1815-1884], [Antoniego] Walewskiego [1805-1876], [Antoniego] Małeckiego [1821-1913], Muczkowskiego. [...] Muczkowski wykładał bibliografię i nauki z nią łączność mające nie z katedry, lecz w sali bibliotecznej, ilustrując je okazami stosownymi. Daru wykładu gładkiego i potoczystego nie miał, dyktował, jąkał się, poprawiał, treść wszakże tych wykładów była ściśle naukowa i wielce pożyteczna. Praktyczna to była i bardzo cenna instrukcja dla bibliografów. Jak wyżej wspomniałem, obok studiów uniwersyteckich rozpocząłem w r. 1850 pracę w Bibliotece Jagiellońskiej. Zacny Muczkowski szczerze się mną zajmował. Sam uczył mnie czytać dokumenta, objaśniał je i komentował swoją głęboką wiedzą, wskazywał dzieła do zawodu bibliograficznego służące, obznajmiał z układem naukowym bogatej Biblioteki Jagiellońskiej, gorąco zachęcał do kształcenia się różnostronnego i specjalnego, jak miłościwy ojciec czuwał nade mną i dopytywał się o moje dążenia. Kiedym już w znajomości zawodu bibliograficznego postąpił i mógł się stać użytecznym, starał się usilnie o wyrobienie mi stałej, płatnej posady amanuensisa w Bibliotece Krakowskiej,

14 Tamże, s. 257.

15 W. Olszewicz, Pamiętnik bibliotekarski Józefa Łozińskiego, „Roczniki Biblioteczne” 1959, R. 3 , z. $1 / 2$, s. $257-280$. 
na której posady utworzenie Ministerstwo nie zezwoliło. Wydał mi wreszcie chlubne świadectwo, które jako cenną pamiątkę przechowuję ${ }^{16}$.

Warto dodać, że szkic-brudnopis zaświadczenia Muczkowskiego dla (niewymienionego z nazwiska) J. Łozińskiego, o jego charytatywnej pracy w BJ, znajduje się w jednym z rękopisów Muczkowskiego, przechowywanych w $\mathrm{BJ}^{17}$. Natomiast czystopis tego dokumentu, datowany 14 VI 1853 r., jest obecnie w Bibliotece Zakładu Narodowego im. Ossolińskich we Wrocławiu ${ }^{18}$.

Obszerne materiały rękopiśmienne J. Muczkowskiego znajdują się w BJ w Krakowie. Stanowią one warsztat i dokumentację jego rozległej, kilkudziesięcioletniej działalności naukowej, wydawniczej i dydaktycznej. Zasoby te przekazali w latach 1893-1896 syn J. Muczkowskiego Stefan (18321895), notariusz, wiceprezydent miasta Krakowa, a w 1915 r. wnuk Józef Jakub Muczkowski (1860-1943, syn Stefana), prawnik, sędzia Sądu Apelacyjnego i historyk sztuki. W tym rozległym i różnorodnym zbiorze znajdują się również materiały do wykładów bibliografii. Najwcześniejsze z nich zawiera rękopis nr 5154 z notatkami Muczkowskiego z wykładów J.S. Bandtkiego, których słuchał w roku akademickim 1815/16. W rękopisach nr 5160, nr 5175 i nr 5790 zgromadzone są notatki i materiały opracowane przez Muczkowskiego do własnych wykładów bibliografii. Natomiast pod numerem 6309 (dawniej sygnatura Fol. 96) znajdują się materiały, przygotowane na podstawie notatek J. Muczkowskiego przez jego syna Stefana, z zamiarem ogłoszenia ich drukiem.

Interesujące źródła do badań recepcji wykładów Muczkowskiego stanowią notatki jego studentów. Należy do nich rękopis nr 5696 ze spuścizny po etnografie, historyku, bibliografie i bibliotekarzu BJ Żegocie Paulim (1814-1895), zawierający niedatowane notatki W. Tymienieckiego, który uczęszczał na wykłady Muczkowskiego. W przekazanej BJ spuściźnie po historyku nauk ścisłych i filozofii, bibliotekarzu, bibliotekoznawcy, historyku książki i bibliofilu Aleksandrze Birkenmajerze (1890-1967) znajdują się również materiały rękopiśmienne należące do jego dziadka ze strony matki (nr Przyb. 191-251/71). Był nim Franciszek Karliński (1830-1906) rówieśnik i kolega K. Estreichera st., wybitny astronom i dyrektor obserwatorium astronomicznego UJ. Wśród przekazanych ze spuścizną A. Birkenmajera papierów F. Karlińskiego są również jego notatki z wykładów słuchanych w latach 1846-1852, między innymi z wykładów bibliografii z roku akademickiego 1846/47. W 2007 r. ukazał się w „Rocznikach Bibliotecznych” artykuł Grzegorza Fulary i Ewy Malickiej o Spuściźnie po Aleksandrze Birkenmajerze w Bibliotece Jagiellońskiej,

\footnotetext{
16 W. Olszewicz, dz. cyt., s. 263, 265.

17 BJ, rps nr 5160, t. 2: Notatki do dyplomatyki [i rękopisoznawstwa], k. 117v.

18 Ossol., rps nr 6515/II, Muczkowski J., Listy i materiały; list J. Muczkowskiego do J. Łozińskiego z 14 czerwca 1853 r., k. 315 r; W. Olszewicz, dz. cyt., s. 265.
} 
podający tę informację ${ }^{19}$. Wcześniej natomiast, wiadomość o rękopisie F. Karlińskiego, będącym w posiadaniu A. Birkenmajera, podał dwukrotnie Stefan Vrtel-Wierczyński w pracach: Bibliografia, jej istota, przedmiot $i$ poczatki ${ }^{20}$ oraz Teoria bibliografii $w$ zarysie ${ }^{21}$.

Studentem J. Muczkowskiego był także, już wcześniej wymieniony, J. Łoziński. W Ossolineum przechowywane są jego notatki z wykładów Muczkowskiego w r. 1850 i w półroczu zimowym r. akad. 1851/52 (nr 6124/I oraz nr 6122/I).

Muczkowski wykładał bibliografię przez 21 lat, w okresie 1837-1858. Pełny kurs bibliografii trwał rok akademicki z zajęciami w wymiarze trzech godzin tygodniowo. W 1850 r. włączył główne gałęzie nauk pomocniczych historii do zakresu dotychczasowych wykładów bibliografii, wydłużając zajęcia o jedno półrocze. I od tego czasu powtarzał kurs co trzy półrocza w cyklu prelekcji o niezmienionym wymiarze trzech godzin tygodniowo. Oprócz bibliografii jako głównego przedmiotu - wykładał:

numizmatykę powszechną i polską, dyplomatykę, czasem prowadzoną łącznie z paleografią praktyczną, heraldykę, wreszcie źródłoznawstwo (nauki dające poznawać źródła historyczne). W ten sposób J. Muczkowski stał się ojcem tych nauk w kursie uniwersyteckim, zarówno w Krakowie, jak w ogólności w naszym szkolnictwie akademickim ${ }^{22}$.

Temat jego wykładów poświęconych naukom pomocniczym historii nie wchodzi jednak w zakres niniejszej pracy.

Muczkowski uważał, że terminy „,bibliografia”, „bibliognozja” i „bibliologia" są równoznaczne, tzn. że pojęcia te mają ten sam zakres treściowy. Pojmował bibliografię jako naukę o książce w najszerszym znaczeniu. Włączył do jej zakresu grafikę, tj. dzieje języków i pism, oraz rękopisoznawstwo (wraz z dyplomatyką, sfragistyką i chronologią), drukarstwo i jego dzieje, bibliotekarstwo i historię bibliotek. W materiałach do wykładów temat bibliografii jako dyscypliny naukowej znajduje się w kilku miejscach i ma kilka -zwięźlejszych lub szczegółowszych - opracowań. Wśród nich jest następujące:

$\mathrm{B}[$ ibliogra]fia, $\mathrm{B}[$ iblio]gnozja także $\mathrm{B}$ [iblio]logia nazywana jest zbiorem wiadomości poznawanie ksiąg ze względu na ich materialność ułatwiających. [...] B[ibliogra]fia uważa książki według ich zewnętrznych własności, ich losu i innych historycznych okoliczności; została ona szczególniej wydoskonalona we Francji i Anglii. Gdy wszelkie pomniki piśmiennych płodów umysłu ludzkiego pod trojakim względem mogą być uważane, bo albo są pisane, albo drukowane, albo samoistnie lub w licznym uważają się zbiorze, zatem trudniąca się

19 G. Fulara, E. Malicka, Spuścizna po Aleksandrze Birkenmajerze w Bibliotece Jagiellońskiej, „Roczniki Biblioteczne” 2007, R. 51, s. 44.

20 S. Vrtel-Wierczyński, Bibliografia, jej istota, przedmiot i początki, Lwów 1923, s. 34 przypis 1.

21 S. Vrtel-Wierczyński, Teoria bibliografii w zarysie, Wrocław 1951, s. 45 przypis 1.

22 H. Barycz, Schytek katedry bibliografii na Uniwersytecie Jagiellońskim i niedoszła profesura tego przedmiotu Karola Estreichera, [w:] Księga pamiątkowa ku czci Karola Estreichera. Studia i rozprawy, [red. R. Hennel], Kraków 1964, s. 32. 
niemi [sic!] bibliogr[afia] na trzy dzieli się części, tj. na grafikę, historię drukarstwa i książnictwo czyli bibliotekarstwo. Grafika wskazuje środki rozpoznawania i ocenie[nia] wieku ksiąg pisanych czyli rękopisów; historia drukarstwa mówi o wynalazku tej sztuki, jej rozroście i upowszechnieniu się; bibliotekarstwo zaś wskazuje sposoby umiejętnego układania ksiąg, spisywania ich, robienia katalogów i należytego chodzenia około całkowitego ich zbioru, aby ten do użycia tak obecnych jak i potomnych jak najprzystępniejszym uczynić ${ }^{23}$. I jeszcze jedno opracowanie, wcześniejsze i w nieco innym ujęciu tematu:

$\mathrm{B}$ [ibliogra]fia jest to zbiór nauk i wiadomości poznawanie ksiąg i ich ocenianie ułatwiające uważanych ze względu na ich materialność. B[ibliogra]fia dzieli się na 3 części: grafikę, historię drukarstwa i bibliotekarstwo. Grafika wskazuje środki rozpoznawania ksiąg pisanych, zastanawia się a) nad materiałami i narzędziami piśmiennemi [sic!], b) nad pismem głoskami i rozmaitymi piśmiennymi znaczkami, c) nad ocenianiem rękopismów z ich materialnego stanu. Historia drukarstwa wystawia wynalazek druku, jego rozrost i upowszechnienie. Bibliotekarstwo wskazuje sposoby umiejętnego układania ksiąg, spisywania ich, robienia katalogów, należytego chodzenia około nich ${ }^{24}$.

Wśród notatek profesora są również pytania egzaminacyjne. Spotykamy je w rękopisach nr 5160, nr 5175 i nr 5790. Sformułowane na piśmie przez wykładowcę pytania egzaminacyjne z czasów uniwersyteckiego nauczania bibliografii w szerokim zakresie (tj. bibliologii) na ziemiach polskich w XIX w., nadal pozostają aktualne jako sprawdzian wiedzy bibliologicznej. Jako jedyne istniejące i nieznane do tej pory bibliologom stanowią wielką rzadkość. Są unikatem. Zanim jednak pytania, zostaną przedstawione, należy podać ogólną charakterystykę rękopisów, w których zostały one umieszczone.

Obszerne notatki i materiały J. Muczkowskiego do własnych wykładów bibliografii cechuje niejednolitość opracowania i rozmaitość formy zewnętrznej (postaci fizycznej). Gromadzone i uzupełniane w ciągu kilkudziesięciu lat, służyły nie tylko do prowadzenia zajęć dydaktycznych. Dla wykładowcy, który ich nie odczytywał, lecz wygłaszał, pełniły jedynie rolę pomocniczą - tekstową, faktograficzną i źródłową. Bardzo trafnie określił zajęcia Muczkowskiego Estreicher st., nazywając je ,pamięciowym wykładem z kartek”25.

Muczkowski wykorzystywał do pisania czyste karty (a także części kart) różnej jakości, formatu i koloru (kremowego i bladoniebieskiego) papieru. Używał również bardzo zróżnicowanej, tak pod względem postaci fizycznej jak i treści, makulatury. Sporządzał notatki np. na niezapisanych stronach verso nieaktualnych rewersów bibliotecznych, brudnopisach oficjalnych sprawozdań bibliotecznych do rektora UJ, czy też arkuszach z urzędowym nadrukiem. Notatki pisane były atramentem o różnej intensywności czerni (tylko niezwykle

\footnotetext{
23 BJ, rps nr 5790, t. 1: Bibliografia, k. 151r-v.

24 Tamże, k. 23r-v.

25 Album biograficzne zastużonych Polaków..., s. 417.
} 
rzadko ołówkiem), zarówno dużym, starannym pismem, jak i mniejszym oraz mniej starannym - świadczącym o pośpiechu notującego. Tworzone w różnych okresach, w znacznych odstępach czasu, były również dopisywane na marginesach lub pomiędzy wierszami tekstu zasadniczego, a także na najbliższym wolnym miejscu. Niekiedy tekst był napisany „do góry nogami”. Wśród notatek znajdują się teksty zarówno autorstwa samego Muczkowskiego, jak i innych uczonych, zarówno polskich jak i obcych - głównie w języku niemieckim i łacińskim, rzadko tylko francuskim. Muczkowski przepisywał wybrany tekst, niekiedy uzupełniając go i zwięźle komentując, albo bardziej lub mniej szczegółowo omawiał odpowiednie części i fragmenty z wybranych dzieł uwzględnianych autorów. Obcojęzyczne teksty albo notował w wersji oryginalnej, albo je tłumaczył lub tylko omawiał. Niekiedy notatki mają charakter drobnych uwag typu „memo", rejestrujących fakty, daty, nazwiska uczonych o identycznych lub odmiennych poglądach, dotyczących referowanego tematu. A licznie uwzględniane informacje bibliograficzne zawierają czasami krótką ocenę zanotowanych dzieł i/lub prezentację przedstawionych w nich poglądów. Stopień szczegółowości i/lub kilka wersji opracowania (mniej lub bardziej rozbudowane, niekiedy zaś tylko szkicowe) poszczególnych tematów świadczą, że notatki były także warsztatem pracy naukowej Muczkowskiego, dokumentacją jego zainteresowań badawczych. Prowadzone przez wiele lat zajęcia wymagały aktualizacji. Nie zawsze jednak kolejne wersje tego samego tematu znajdują się wśród odpowiadających im treściowo notatek. Sukcesywnie aktualizowane i uzupełniane było również piśmiennictwo dotyczące uwzględnianej tematyki, zagadnienia lub faktu, z położeniem nacisku na rodzimą literaturę przedmiotu. $\mathrm{Z}$ biegiem czasu notatki były także wzbogacane najnowszymi, licznymi i interesującymi wiadomościami faktograficznymi, niekiedy o charakterze ciekawostek. Aktualizacja treści notatek tekstowych, bibliograficznych i faktograficznych znajduje się pomiędzy wierszami tekstu zasadniczego, na marginesie, na celowo zostawionych do uzupełnień, wcześniej niezapisanych miejscach kart. Dopiski są zazwyczaj pisane drobniejszym pismem i ciemniejszym atramentem niż tekst zasadniczy, świadcząc o późniejszym niż on powstaniu. Niekiedy podane są również, tak w tekście głównym notatek, jak i w dopiskach, sygnatury lub skrócone opisy egzemplarzy omawianych dzieł, znajdujących się w zbiorach BJ.

W notatkach brak czystopisu tekstu wykładów. I można twierdzić, że nigdy nie istniał. Brak również rozgraniczenia tekstu wygłoszonego od napisanego. Brak także numeracji i datowania lekcji. Znajdujące się w notatkach daty wskazują raczej na czas rozpoczęcia, powstawania i/lub zakończenia pisania tekstu, tj. opracowywania danego tematu. Zanotowana data nie wskazuje terminu, w jakim odbył się wykład na dany temat. Ponadto, lektura notatek nie umożliwia odtworzenia w pełni kolejności wykładanych szczegółowszych tematów 
i przeznaczonego im czasu. Brakuje w nich także wskazówek, jak długo trwał jeden cykl tematyczny i wchodzące w jego zakres węższe zagadnienia. Poza tym, można jedynie stwierdzić istnienie wprowadzanych z biegiem lat pewnych zmian w wykładanych treściach i ich aktualizację: w kolejności tematów, preferencjach tematycznych wykładowcy, pomocach metodycznych wykorzystywanych na zajęciach np. z dyplomatyki, paleografii, rękopisoznawstwa. Nie można jednak wskazać precyzyjnie czasu ich powstania. Mógłby być osobnym obszarem rozważań temat, jak prowadzone równolegle z wykładami, własne prace naukowe Muczkowskiego, wpływały na treść i ujęcie jego zajęć dydaktycznych.

Z lektury notatek można odnieść wrażenie, że Muczkowski nie miał zamiaru gromadzonych i opracowywanych przez siebie materiałów ogłosić drukiem jako uniwersyteckiego podręcznika do nauki bibliografii. Można jednak również myśleć, że Muczkowski zamierzał opublikować wykłady, lecz nadmiar innych niż dydaktyczne prac i obowiązków uniemożliwiał mu realizację tego projektu. Oba te przypuszczenia zdaje się potwierdzać dużo późniejsza inicjatywa S. Muczkowskiego, aby opublikować wykłady ojca. Niestety, rozpoczęta przez niego praca, zaplanowana na ogłoszenie drukiem w 1871 r. jako „Wykłady bibliografii ś. p. Józefa Muczkowskiego profesora i bibliotekarza Uniw[ersytetu] Jag[iellońskiego] miewane w latach ........ wydał [następuje dopisana inną ręką uwaga:] (nie wyszły) Stefan Muczko[wski] Kraków 1871 r.”, pozostała w rękopisie nieukończona zarówno treściowo, jak i edytorsko. BJ otrzymała ją dopiero w 1915 r. od J.J. Muczkowskiego. Rękopis ten, będący głównie autografem S. Muczkowskiego (obecnie nr 6309 dawniej sygnatura Fol. 96), wymieniłam już wcześniej. Pokaźny objętościowo tekst (IV, 464 s.) dotyczy jedynie grafiki czyli ,pismoznawstwa” (tj. mowy, języków, początków pisma i pism u poszczególnych ludów) oraz dyplomatyki, sfragistyki, heraldyki, chronologii, ,dyplomatyki praktycznej” i ,praktycznego rękopismoznawstwa” a także numizmatyki - w tym numizmatyki polskiej (do czasów Królestwa Kongresowego). Brak opracowania i przygotowania do druku tekstu dotyczącego drukarstwa i bibliotekarstwa, które J. Muczkowski włączał do zakresu wykładanej bibliografii jako jej drugą i trzecią część składową.

***

Pytania egzaminacyjne J. Muczkowskiego znajdują się w trzech rękopisach ze zbiorów BJ: nr 5160, nr 5175 i nr 5790.

Rękopis nr 5160 zawiera dwa tomy i w sumie liczy 400 kart: t. 1 „Dyplomatyka” (kart 194) i t. 2 „Notatki do dyplomatyki [i rękopisoznawstwa]” (kart 206, w układzie według opisanego już wcześniej rękopisu nr 6309). Znajdują się w nich własne opracowania Muczkowskiego: oryginalne teksty i thumaczenia fragmentów prac innych autorów z uzupełnieniami i komentarzami profesora 
oraz ekscerpta z dzieł zagranicznych w języku niemieckim i łacińskim, a także polskim - głównie z pracy Joachima Lelewela (1786-1861) Nauki dajace poznawać źrzódła [sic!] historyczne, wydanej w Wilnie w 1822 r. Ponadto, na licznych kartach i kartkach (także makulaturowych) zgromadzone są notatki zawierające interesujące szczegóły faktograficzne z historii powszechnej i polskiej. Muczkowski gromadził je z rozmaitych dokumentów, których podobizny służyły na zajęciach z dyplomatyki i paleografii jako pomoce metodyczne $\mathrm{w}$ doskonaleniu umiejętności czytania rozmaitych duktów pism. Zanotowane przez Muczkowskiego na kartach rękopisu i/lub znajdujące się na wykorzystywanych przez niego do notatek makulaturowych kartach i kartkach daty, świadczą, że materiały opracowywane i gromadzone były sukcesywnie przez wiele lat. Obejmują one okres od 1836 r. (a więc jeszcze przed rozpoczęciem wykładów $\left.{ }^{26}\right)$, poprzez lata 1845, 1847, 1850-1851, 1853-1855.

Zupełnie nieoczekiwanie dla czytelnika, na ostatniej i przedostatniej karcie tomu 1 rękopisu nr 5160 (k. 194r i k. 193r) zapisane są kaligraficznym pismem „Pytania z bibliografii z drugiego półrocza”. Jest to 18 ponumerowanych pytań: dziewięć z historii drukarstwa w Polsce i dziewięć dotyczących praktycznego bibliotekarstwa. Można sądzić, że tylko przez przypadek zostały umieszczone $\mathrm{w}$ rękopisie zawierającym materiały z zakresu dyplomatyki. Na karcie 194r znajduje się 16 pytań: dziewięć dotyczy drukarstwa, a siedem jest poświęconych bibliotekarstwu. Dwa następne pytania, nr 17 i nr 18, dotyczące bibliotekarstwa (rodzajów katalogów) zapisane są na początku karty 193r. Zapis pytań jest niepodobny do duktu pisma Muczkowskiego. Można przypuszczać, że pytania były napisane inną ręką niż ręka wykładowcy. Może napisał je pod dyktando lub przepisał z brudnopisu notatek profesora któryś ze studentów, albo ktoś z bliskiego kręgu Muczkowskiego? O tym, że pytania napisała inna osoba mogą również świadczyć dwa językowe „potknięcia”. W pytaniu dziesiątym bowiem (k.194r) zamiast rzeczownika „zabezpieczenia" jest jego zapis „zabezbieczenia”. Natomiast w pytaniu 18 (k. 193r) na określenie jednego z wymienionych rodzajów katalogów (obecnie nazywanym katalogiem topograficznym), zamiast przymiotnika „repozytorialne” jest jego zapis „repozytolialne”.

W rękopisach nie ma żadnych informacji o okolicznościach i czasie sporządzenia wykazu „Pytań z bibliografii z drugiego półrocza”, ani od kiedy służył jako sprawdzian wiedzy studenckiej. Nie wiadomo również, czy z biegiem lat pytania były modyfikowane. Dowodem, że Muczkowski czytał pytania i korzystał z nich, są dopisane przez niego jako uzupełnienie wykazu (drobniejszym pismem i ciemniejszym atramentem, później niż kaligraficzny tekst pierwotny) trzy ponumerowane pytania z początków drukarstwa w Polsce. Dwa z nich

26 Zob. np. datę przy tekście o palimpsestach: BJ, rps nr 5160, t. 2, k. $153 \mathrm{v}$. 
dopisał pomiędzy kaligraficznie napisanym tytułem i pytaniem pierwszym. Natomiast trzecie dopisane przez niego pytanie zmieściło się pomiędzy pierwotnymi, kaligraficznie napisanymi pytaniami jeden i dwa.

Poniżej podano zapis pytań, zachowując jego ortografię, interpunkcję i numerację:

Pytania z Bibliografii z drugiego półrocza

1. O najdawniejszych drukach w Polsce? bę [sic!] będących

2. O drukach Hallerowskich

1. Ile było drukarzy Szarfenbergami zwanych i jakie są celniejsze dzieła u nich wydane.

3. O celniejszych drukarzach krakowskich?

2. O drukarni Łazarzowskiej i drukach celniejszych

3. O drukach Wierzbięty

4. O drukarni Piotrkowczyków

5. O drukarni Cezarych.

6. Jakie były celniejsze drukarnie za Krakowem w końcu wieku XVI i na początku XVII.

7. Skreślić wiadomość o początku drukarń Rakowskich

8. O więdnieniu [sic!] drukarstwa w Polsce

9. O odżyciu drukarstwa i jego zakwitnieniu [sic!]

10. Co trzeba uważać względem zabezbieczenia [zabezpieczenia] bibliotek i książek

11. Jak się postępuje przy uporządkowaniu biblioteki

12. Iloraki jest sposób szykowania ksiąg w bibliotekach

13. Jak się spisują książki

14. Co są katalogi cedułkowe, jak się robią i do czego służą

15. Do czego potrzebne znaczenie spisanych ksiąg, ilorakie jest i jak się przybytki znaczą

16. Jak się przystępuje do spisywania katalogu alfabetycznego.

17. Ilorakie mogą być katalogi i które z nich najpotrzebniejsze

18. Co to są katalogi systematyczne, co realne a co repozytolialne [repozytorialne].

Należy jeszcze znaznaczyć, że na karcie 193r, po kaligraficznie napisanym pytaniu 18, znajdują się notatki, napisane drobnym „zwykłym” pismem Muczkowskiego, zawierające tematy z zakresu dyplomatyki i grafiki. Sformułowane w ponumerowanych punktach (od 26 do 41) mogły stanowić sporządzony na podstawie lektur szkic dyspozycji wykładów lub/i plan zamierzonej przyszłej publikacji. Wypunktowane tematy z zakresu dyplomatyki i grafiki nie były zaplanowane jako pytania egzaminacyjne, chociaż niektóre, ze względu na ich sformułowanie, sprawiają wrażenie, że mogłyby pełnić również taką rolę.

Rękopis BJ nr 5175 zawiera „Różne materiały J. Muczkowskiego” na 194 kartach. Znajdują się w nim kopie historycznych dokumentów: akt, korespondencji i pamiętników, dotyczących wydarzeń z dziejów Polski, a także notatki Muczkowskiego do przygotowywanej pracy o czasach Jadwigi i Jagiełly i o ich 
wizerunkach ${ }^{27}$. Zgromadzone materiały mogły być wykorzystane do opracowania wykładów dyplomatyki i rękopisoznawstwa, jak również jako pomoce metodyczne, np. do ćwiczeń z paleografii, jednocześnie wzbogacając wiedzę studentów wiadomościami z historii ojczystej. Znamiennym przykładem może być obecna karta 130r, którą Muczkowski scharakteryzował, notując na jej dolnej części: „Niniejszy szpargał z okładki starej książki wydarty dlatego się tu umieściło, że zawiera kilka szczegółów życia biskupów tyczących się. Poznań 31 grud[nia] 1828". Muczkowski opisał tę kartę (właściwie będącą kopią dokumentu) już w 1828 r., a więc dziewięć lat wcześniej zanim rozpoczął wykłady na UJ. Wówczas posłużyła mu do innych celów.

Wśród tak różnorodnych materiałów rękopisu nr 5175, na karcie 148r znajduje się sześć numerowanych pytań. Pytanie siódme nie zostało sformułowane, Muczkowski zapisał tylko jego numer. Brak tytułu (nagłówka) i niekaligraficzne, „Zwykłe" pismo wskazuje, że jest to raczej brudnopis planowanych przez profesora pytań egzaminacyjnych. Ponadto, napisane są w nietypowy sposób: wzdłuż drugiej (dolnej) połowy karty, poczynając od jej prawego brzegu.

Pierwsze z pytań dotyczy definicji bibliografii, kolejne cztery (numery 2, 3, 4 i 6) rodzajów języków i jedno (nr 5) rodzajów pism u Słowian. Tematyka pytań nie dotyczy więc treści zgromadzonych w rękopisie materiałów. Znalazły się w tym zbiorze notatek - podobnie jak pytania umieszczone w tomie pierwszym rękopisu nr 5160 - tylko przez przypadek. Podano zapis tych pytań, zachowując jego interpunkcję i skreślenie tekstu:

1. Co jest bibliografia i jak się dzieli?

2. Jak się dzielą językiNa ile klas dzielimy znane dotąd języki.

3. Wyliczyć języki jakich narody na zachód Europy mieszkające używały lub używają.

4. Podział Słowian ze względu na ich mowę i wyszczególnić celniejsze dialekty słowiańskie.

5. Czy wszyscy Słowianie jednego używają pisma i czem [sic!] się pod tym względem między sobą różnią.

6. Które to są języki w Europie, których początek jest wątpliwy.

Spośród bibliologicznych materiałów Muczkowskiego najważniejszy z punktu widzenia wykładów bibliografii jest trzytomowy rękopis $\mathrm{nr}$ 5790, liczący w sumie 667 kart. W skład jego wchodzi t. 1 „Bibliografia” (kart 321), t. 2 „Drukarstwo” (kart 217) i t. 3 „Biblioteki i bibliotekarstwo” (kart 129).

Na początku tomu pierwszego ${ }^{28}$ znajduje się „Wstęp” Ż. Paulego i notatki S. Muczkowskiego. Zawierają one informacje o etapach prac nad przygotowaniem do wydania rękopiśmiennych materiałów J. Muczkowskiego do wykładów bibliografii i nauk pomocniczych historii oraz spis treści (przyjęty układ)

\footnotetext{
27 BJ, rps nr 5175, Różne materiały J. Muczkowskiego, k. 147r-166v.

28 BJ, rps nr 5790, t. 1, k. 1r-20v.
} 
przyszłego dzieła. Teksty te świadczą o rozpoczętych, lecz (jak wykazała rzeczywistość) niedokończonych próbach uporządkowania i zaniechanych usiłowaniach zredagowania i opublikowania wybranych materiałów. Planowana praca miała ukazać się drukiem - zgodnie z przyjętym tytułem - jako „Wykład bibliografii i nauk pomocniczych historycznych. Dzieło pozgonne ś.p. J. Muczkowskiego Dra Fil. Prof. itd. z pozostałych rękopismów zebrane i wydane przez St. M." ${ }^{29}$. Warto zaznaczyć, że rezultatem tych niezrealizowanych planów wydawniczych i niedokończonych edytorskich zabiegów jest uporządkowanie rękopisu nr 5790 (zwłaszcza jego najbardziej „chaotycznego” treściowo tomu pierwszego) oraz powstanie rękopisu nr 6309 (dawniej sygnatura Fol. 96 ) - już dwukrotnie wymienionego.

Wśród materiałów tomu pierwszego dominujące są notatki do dziejów i charakterystyk języków i pism - obszerne i różnorodne, niektóre opracowane w kilku wersjach i umieszczone w różnych miejscach. Zwięzłe teksty dotyczące szeroko pojmowanej bibliografii jako nauki, teoria i zakres dyscypliny z definicjami jej zasadniczych działów, również są opracowane w kilku wersjach i umieszczone w różnych miejscach tomu pierwszego ${ }^{30}$. Stosunkowo mało jest notatek na temat wynalazku druku i dziejów drukarstwa w Polsce zaledwie kilkanaście kart ${ }^{31}$, a najkrótszy jest tekst poświęcony bibliotekarstwu, właściwie stanowi lakoniczną notatkę, zajmującą dwie karty ${ }^{32}$.

Tom drugi zawiera notatki do historii drukarstwa powszechnego i dziejów drukarstwa w Polsce do początków XIX w. Tekst o stronie technicznej procesu drukowania jest dość obszerny, liczy 14 kart $^{33}$.

Tom trzeci jest $\mathrm{w}$ porównaniu $\mathrm{z}$ tomami poprzednimi najmniejszy objętościowo. Są w nim przede wszystkim notatki Muczkowskiego z jego lektur, uzupełnione zwięzłym komentarzem. Najobszerniejsze materiały dotyczą dziejów powszechnych bibliotek ${ }^{34}$, historii bibliotek w Polsce ${ }^{35}$, zagadnień rękopisoznawstwa: „Praktyczne rękopismoznawstwo" ${ }^{36}$ i „O rękopismoznawstwie" ${ }^{37}$ oraz praktycznego bibliotekarstwa ${ }^{38}$. Notatki do historii bibliotek opracowane zostały w zasadzie do roku 1500 , lecz istnieje również kilka faktograficznych zapisków dotyczących czasów późniejszych, do końca wieku XVIII. Materiały te zostały przygotowane na podstawie prac wielu uczonych,

\footnotetext{
29 BJ, rps nr 5790, t. 1, k. 1r.

30 Tamże, k. 2r, 23r, 89r, 150r, 151r-v, 163r.

31 Tamże, k. 70r-83v.

32 Tamże, k. 83v-85r.

33 BJ, rps nr 5790, t. 2: Drukarstwo, k. 83r-96v.

34 BJ, rps nr 5790, t. 3: Biblioteki i bibliotekarstwo, k. 2r-36r.

35 Tamże, k. 45r-56r.

36 Tamże, k. 59r-64v

37 Tamże, k. 65r-74v.

38 Tamże, k. 75r-99r.
} 
które Muczkowski wymienił, lecz najbardziej skorzystał z wydanych w Warszawie w 1828 r. Dziejów bibliotek do Dziennika Warszawskiego J. Lelewela i z jego Historycznego obrazu bibliotek w Polszcze [sic!], opublikowanego dwa lata wcześniej w Bibliograficznych ksiag $d w o j e . . .{ }^{39}$ Notatki dotyczące rękopisoznawstwa natomiast przygotował na kanwie uznanej za klasyczną pracy Friedricha Adolfa Eberta (1791-1834) Zur Handschriftenkunde z 1825 r. ${ }^{40}$ Pomiędzy tymi materiałami znajdują się krótsze, kilku- lub jednokartowe notatki, m.in. o wynalazku i początkach drukarstwa ${ }^{41}$, definicje dziedzin wchodzących w zakres szeroko pojmowanej bibliografii ${ }^{42}$, czy też wykaz piśmiennictwa do dziejów bibliotek publicznych i towarzystw w Polsce ${ }^{43}$, sporządzony przez inną osobę niż J. Muczkowski na podstawie pracy niemieckiego bibliotekarza i bibliografa Ernsta Gustava Vogla (1797-1874) Literatur früherer und noch bestehender europäischer öffentlicher und Corporations-Bibliotheken ${ }^{44}$.

Po materiałach poświęconych praktycznemu bibliotekarstwu umieszczone są drobne notatki bibliograficzne i faktograficzne do historii bibliotek, historii drukarstwa, rękopisoznawstwa i dziejów pism. Skupione zostały pod tytułem napisanym pismem dwóch rąk. Cytując, odróżniamy je wielkością czcionki: „Literatura dzieł pomocniczych do niniejszego dzieła Muczkowskiego. Jeżeli wypadnie na końcu jako przydatek" ${ }^{45}$. Jest to jeszcze jeden dowód na prace S. Muczkowskiego i Ż. Paulego nad realizacją niedokończonego projektu wydawniczego wykładów J. Muczkowskiego. Następnie umieszczony jest „Wykaz dzieł bibliograficznych [tj. bibliologicznych] i numizmatycznych, które się w bibliotece uniwersyteckiej [tj. Jagiellońskiej] znajdują"46. Sporządził go J. Muczkowski, przyjmując dla uwzględnionych pozycji opis skrócony, niekiedy z adnotacjami treściowymi i bardzo często z podaniem sygnatury BJ. Ponadto, w „Wykazie” uwzględnił odrębnie „Dzieła dla bibliotekarzy” ${ }^{47}$.

Na końcu tomu znajduje się siedem nienumerowanych pytań egzaminacyjnych (k. 127r). Trzy z nich poświęcone są historii drukarstwa (tj. dwa dotyczą historii powszechnej drukarstwa i jedno pytanie jest na temat początków

39 J. Lelewel, Bibliograficznych ksiag dwoje, w których rozebrane i pomnożone zostały $d w a$ dzieła Jerzego Samuela Bandtke Historia drukarń krakowskich tudzież Historia Biblioteki Uniw. Jagiell. w Krakowie a przydany katalog inkunabułów polskich. T. 2, Wilno 1826, s.77-184; J. Muczkowski przejął tylko tekst zawarty na s. 80-87, zob. BJ, rps nr 5790, t. 3, k. 45r-v - 46r-v.

40 F.A. Ebert, Zur Handschriftenkunde. Erstes Bändchen, Leipzig 1825.

41 BJ, rps nr 5790, t. 3, k. 36v-41v.

42 Tamże, k. 44r-44v.

43 Tamże, k. 49r-52v.

44 Leipzig 1840, zob. rozdział pt. Russland und Polen. Schriften und Abhandlungen über Russlands und Polens Bibliotheken überhaupt, s. 511-525.

45 BJ, rps nr 5790, t. 3, k. 100r-v, 101r-v, 102r, 104r-v.

46 Tamże, k. 106r-126r.

47 Tamże, k. 115r-123r. 
drukarstwa w Polsce), kolejne trzy poświęcone są bibliotekarstwu i jedno historii bibliografii. Nie ma pytań dotyczących historii bibliotek, chociaż Muczkowski opracował notatki poświęcone tej tematyce. Pytania te, tak samo jak pytania znajdujące się w rękopisie $\mathrm{nr} 5175^{48}$, również mają postać brudnopisu. Napisane są niekaligraficznym, „zwykłym” pismem z licznymi skreśleniami sformułowań pierwotnych. I także zanotowane są wzdłuż prawego brzegu karty - w jej drugiej (dolnej) połowie. Podano zapis pytań, zachowując liczne skreślenia pierwotnych sformułowań, skróty wyrazów i interpunkcję, a wprowadzając jedynie numerację:

[1.] Wspomnieć celniejszych drukarzy od w. XVI. Wyliezyé niektóre druki eelniejsze druki w pier

[2.] Wskazać dzieła które dzieła w pierwszych latach wynalazku druku ogłoszono?

[3.] Skreślić rys historii bibliografii polskiej? Jakie sáźódla do przesz[tośei] bibliografiti polskiej?

Którzy byli eelniejsi drukarze-

[4.] Kiedy druk do Polski wprowadzono i którzy byli celniejsi drukarze?

[5.] Ilorakie są systemata co do układu bibliotek? i w i jakie s

[6.] Jak postępu się postępuje w uporządkowaniu biblioteki?

[7.] Jak się uk Ilorakie mogą być katalogi biblioteczne i jak się układają?

Ostatnimi kartami tomu ${ }^{49}$ są dwa przekreślone rewersy wypożyczeń z BJ: z 15 VII 1842 r. i z 15 IV 1845 r., na odwrocie którego są bibliograficznohistoryczne notatki Muczkowskiego ${ }^{50}$.

Podstawą do przygotowania notatek do wykładów bibliotekarstwa i inspiracją dla własnych przemyśleń, kształtowania się poglądów, a zapewne także dla przyjętych procedur w zarządzaniu BJ i jej funkcjonowaniu były dla Muczkowskiego dzieła z zakresu bibliotekoznawstwa europejskich uczonych-humanistów, którzy byli również wybitnymi bibliotekarzami-praktykami i teoretykami tej dyscypliny. Notatki Muczkowskiego dotyczące bibliotekarstwa są jednak oparte przede wszystkim na Lelewelowskim Bibliotekarstwie czyli książnictwie, umieszczonym przez historyka w jego pionierskim dziele Bibliograficznych ksiag $d$ woje... ${ }^{51}$ Muczkowski przejął $\mathrm{z}$ tej pracy nie tylko konstrukcję rozdziału o bibliotekarstwie, lecz także niemal dosłownie przepisał większość tekstu, niekiedy tylko parafrazując go lub omawiając. Identyczne lub odmienne od koncepcji Lelewela poglądy innych luminarzy bibliotekoznawstwa - teoretyków i praktyków bibliotekarstwa, dotyczące rozwiązań szczegółowszej problematyki, przepisywał Muczkowski w oryginale lub tłumaczył albo tylko

\footnotetext{
48 BJ, rps nr 5175, k. 148r.

49 BJ, rps nr 5790, t. 3, k. 128r-v - k. 129r-v.

50 Tamże, k. $129 \mathrm{v}$.

51 T. 2, Wilno 1826, s. 261-339.
} 
omawiał. Umieszczał je w odpowiednich miejscach notatek „z Lelewela" lub odrębnie - jeśli były rozwinięciem tematu albo jego indywidualnym autorskim, drobiazgowym ujęciem. W nawiasie podawał nazwisko autora zanotowanych i zacytowanych poglądów i numer strony pracy, w której były opublikowane. Na wstępie notatek poświęconych bibliotekarstwu umieścił Muczkowski definicję tej dyscypliny, która wciąż jest aktualna. Zanotował:

Bibliotekarstwo uczy, jak chodzić koło całkowitego składu ksiąg, aby go do użycia powszechnego najprzystępniejszym uczynić. Dawniej niejasne o bibliotekarstwie wyobrażenia mieszały księgarstwo z bibliotekarstwem. Lelewel je książnictwem, a bibliotekarza książnym nazywa ${ }^{52}$.

Podając źródła do wykładów bibliotekarstwa, Muczkowski wymienił ${ }^{53}$ następujące prace: F.A. Eberta Die Bildung des Bibliothekars ${ }^{54}$, Christiana Molbecha Über Bibliothekswissenschaft, oder Einrichtung und Verwaltung öffentlicher Bibliotheken ${ }^{55}$, Martina Schrettingera Handbuch der Bibliothekswissenschaft $\ldots{ }^{56}$, zaznaczając że podręcznik ten jest streszczeniem wydanego wcześniej pierwszego tomu Versuch eines vollständigen Lehrbuches der Bibliothekswissenschaft ${ }^{57}$. Wskazał także jako źródłowe, jeszcze cztery pozycje: Petera Alcantary Budika Vorbereitungsstudien für den angehender Bibliothe$k a r^{58}$, Jeana Pie Namura Manuel du bibliothécaire, accompagné de notes critiques, historiques et littéraires ${ }^{59}$ i Johanna Christopha Friedricha Kritische Erörterungen zum Übereinstimmenden Ordnen und Verzeichnen öffentlicher Bibliotheken ${ }^{60}$ a także Arnolda Hermanna Ludwiga Heerena Christian Gottlob Heyne. Biographisch dargestellt ${ }^{61}$. Warto dodać, że 11 lat wcześniej od Muczkowskiego Lelewel, wymieniając prace Schrettingera, Eberta i Heerena zaznaczył w Bibliograficznych ksiag dwoje.... „,Te dzieła są źrzódłem [sic!] i pobudką do tego, co tu o bibliotekarstwie napiszę"

Należy podkreślić, że wymieniony już wcześniej jako autor pracy o rękopisoznawstwie (Zur Handschriftenkunde), wybitny niemiecki bibliotekarz i bibliograf F.A. Ebert, pracujący kolejno w bibliotekach: Miejskiej i Uniwersyteckiej w Lipsku, Królewskiej w Dreźnie i Książęcej w Wolfenbüttel,

\footnotetext{
52 BJ, rps nr 5790, t. 3, k. 75r. Por. J. Lelewel, Bibliograficznych ksiag dwoje. T. 2, s. 256.

53 BJ, rps nr 5790, t. 3, k. 75r-v.

$54 \quad 2^{\text {te }}$ umgearb. Ausgabe, Leipzig 1820.

55 Nach der 2. Ausgabe des dänischen Originals übersetzt von H.Ratjen, Leipzig 1833.

56 Pełny tytuł: Handbuch der Bibliothekswissenschaft, besonders zum Gebrauche der Nicht-Bibliothekare, welche ihre Privatbüchersammlungen selbst einrichten wollen, Wien 1834.

57 I.-III. Hefte, München 1808-1810.

58 Wien 1834.

59 Bruxelles 1834.

60 Leipzig 1835.

61 Göttingen 1813.

62 J. Lelewel, Bibliograficznych ksiag dwoje..., T. 2, s. 263.
} 
propagował publiczne udostępnianie zbiorów bibliotek i jako jeden z pierwszych postulował samodzielność zawodu bibliotekarskiego. Duński historyk, profesor literatury i krytyk Ch. Molbech (1783-1857) był bibliotekarzem Wielkiej Biblioteki Królewskiej w Kopenhadze. Jego, uznane za klasyczne, niezwykle popularne i wielokrotnie wydawane w Danii dzieło na temat organizacji i zarządzania biblioteką przetłumaczył na język niemiecki Henning Ratjen (1793-1880) - również uczony (prawnik), profesor i przez prawie 50 lat bibliotekarz Biblioteki Uniwersyteckiej w Kilonii. Muczkowski korzystał z niemieckiego tłumaczenia pracy Molbecha. Poglądy i działalność M. Schrettingera (1772-1851), niemieckiego zakonnika (benedyktyna) i bibliotekarza (po studiach teologicznych) w macierzystym klasztorze w Weissenohe koło Norymbergi (Bawaria) do czasu jego sekularyzacji, a następnie (do końca życia) w Bibliotece Nadwornej w Monachium, utorowały drogę unowocześnieniu bibliotekarstwa. Jego własna koncepcja działowego ustawiania zbiorów bibliotecznych (opracowanie schematu), analiza istniejących katalogów systematycznych i opracowanie katalogu przedmiotowego przyczyniły się do modernizacji pracy bibliotecznej, zwłaszcza organizacji i zarządzania wielkimi księgozbiorami naukowymi.

Muczkowski powoływał się również na poglądy i metodyczne rozwiązania przyjęte przez P.A. Budika (1792-1858) - pochodzącego z Moraw austriackiego bibliotekarza, filologa klasycznego, literaturoznawcę, pisarza i krytyka muzycznego. Budik pracował najpierw w wiedeńskiej Bibliotece Nadwornej, a następnie przez prawie 30 lat był bibliotekarzem Liceum w Klagenfurcie (Celowcu). Oprócz wymienionej w źródłach publikacji Vorbereitungsstudien für den angehender Bibliothekar Muczkowski znał również pracę Budika Vorschule für bibliothekarisches Geschäftsleben ${ }^{63}$. Korzystał z niej, sporządzając notatki dotyczące katalogowania zbiorów i budowy katalogu alfabetycznego. Przepisał nawet podany przez Budika w tej pracy przykład opisu katalogowego zastosowanego w katalogu alfabetycznym ${ }^{64}$. Jean Pie Namur (1804-1867), doktor filozofii i nauk humanistycznych, belgijski bibliograf, bibliotekoznawca i bibliotekarz Uniwersytetu w Lowanium (Leuven) i Biblioteki Królewskiej w Brukseli jest wymieniony przez Muczkowskiego w źródłach do wykładów jako autor Manuel du bibliothécaire... Jest on również autorem trzech obszernych monografii najznamienitszych historycznych bibliotek belgijskich - w Brukseli, Lowanium (Leuven) i Liège ${ }^{65}$. Muczkowski zapewne znał te publikacje, lecz nie wymienił ich

63 München 1848.

64 BJ, rps nr 5790, t. 3, k. 99r; P.A. Budik, Vorschule..., s.139.

65 J.P. Namur, Histoire des bibliothèques publiques de la Belgique. T. 1-3, Bruxelles 1840, Bruxelles at Leipzig 1841-1842; T. 1: Histoire des bibliothèques publiques de Bruxelles, Bruxelles 1840; T. 2: Histoire de la Bibliothèque Publique de Louvain, Bruxelles at Leipzig 1841; T. 3: Histoire 
w notatkach. Na poglądy J.Ch. Friedricha dotyczące układu i opisu zbiorów, tj. rzeczowego ustawienia księgozbioru według przyjętego systemu oraz budowy sygnatur katalogowanych dzieł, powoływał się Muczkowski w notatkach o szeregowaniu (układzie) prac monograficznych, budowie sygnatur i ustawieniu rękopisów ${ }^{66}$.

Obok wymienionych dzieł sześciu autorów, Muczkowski zanotował w wykazie źródeł również obszerną biografię Ch.G. Heynego (1729-1812) ${ }^{67}$. Był on wybitnym niemieckim filologiem klasycznym, profesorem Uniwersytetu w Getyndze, który wprowadził do programu studiów uniwersyteckich wiedzę o kulturze, sztuce i religii starożytnej. Biografię Heynego napisał A.H.L. Heeren (1760-1842), również wybitny niemiecki uczony, profesor filozofii i historii. W pracy tej znajdują się także informacje o Bibliotece Uniwersyteckiej w Getyndze. Założona na przełomie 1735/36 r., modernizująca organizację i tok prac wewnętrznych, była powszechnie uznawana za wzór dla innych bibliotek europejskich. Muczkowski korzystał także z monografii przedstawiającej historię Biblioteki Królewskiej w Berlinie Friedricha Wilkena (1777-1840), niemieckiego historyka i orientalisty, profesora Uniwersytetu w Berlinie ${ }^{68}$. Wilken był w latach 1807-1817 bibliotekarzem uniwersyteckim w Heidelbergu, następnie w Berlinie w Bibliotece Królewskiej i od 1831 r. w nowo utworzonej Bibliotece Uniwersyteckiej. Muczkowski wymienił go, notując: „Urządzenie czytelni zob. Wilken: Gesch. der Königl. Bibliothek zu Berlin i Molbech str. 227’69. Zapewne zrelacjonował i porównał na wykładzie poglądy i rozwiązania przyjęte przez obu uczonych i bibliotekarzy. Spośród zagranicznych autorów najczęściej powoływał się na Molbecha. Rozwiązania, jakie duński bibliotekarz zalecał dla zarządzania i organizacji wewnętrznych prac biblioteki, zajęły w materiałach Muczkowskiego najwięcej miejsca. Notatki o bibliotekarstwie zostały więc opracowane głównie na podstawie Lelewelowskiego rozdziału Bibliotekarstwo czyli ksiąznictwo (umieszczonego w Bibliograficznych ksiag dwoje...) oraz pracy Molbecha Über Bibliothekswissenschaft...

Odrębnym tematem badawczym mogłoby być ustalenie, w jakim stopniu znajomość poglądów tych wybitnych uczonych-humanistów i zarazem luminarzy bibliotekoznawstwa wpłynęła na organizację, metodykę i technikę prac bibliotecznych w BJ w okresie, kiedy Muczkowski był jej dyrektorem. W jego notatkach do wykładów bibliotekarstwa brak jest informacji dotyczących organizacji i metodyki prac bibliotecznych w BJ. Zapewne wiadomości na ten temat przekazywał studentom ustnie, nie zapisując ich.

de la Bibliothèque Publique de Liège, Bruxelles at Leipzig 1842.

66 BJ, rps nr 5790, t. 3, k. 81v-82r, 97r.

${ }_{67}$ BJ, rps nr 5790, t. 3, k. 75v; zob. A.H.L. Heeren, dz. cyt.

68 Geschichte der Königlichen Bibliothek zu Berlin, Berlin 1828.

69 BJ, rps nr 5790, t. 3, k. 91r. 
Publikowane tutaj „Kartki z dziejów nauczania bibliologii” nie mają charakteru rozprawy poświęconej znaczeniu uniwersyteckiego nauczania J. Muczkowskiego dla rozwoju teorii bibliologii jako dyscypliny naukowej w Polsce. Są jedynie zapisem kilku wybranych refleksji po lekturze materiałów rękopiśmiennych z obszernego warsztatu bibliologicznego, wykorzystywanego przez profesora w uprawianej przez niego dydaktyce. I może staną się kiedyś inspiracją do dalszych prac nad znaczeniem jego dydaktycznej działalności w dziejach bibliologii w Polsce - jej teorii i praktyki, dydaktyki i recepcji kształcenia w zakresie tej dyscypliny, widocznej w zmieniającym się poziomie kultury książki w społeczeństwie. Tematy te wciąż czekają na ich podjęcie.

Muczkowski rozpoczął wykłady na UJ 183 lata temu. Z upływem czasu całkowicie zmieniła się polityczna, gospodarcza, społeczna i kulturalna rzeczywistość, w jakiej żyjemy. Jesteśmy inni mentalnie, światopoglądowo i kulturowo. Za sprawą nowych technologii elektronicznych doświadczamy dogłębnych przemian świata książki, jej kultury i komunikowania. Powstała już nowa era w ich rozwoju. Nadal jednak pozostają aktualne ówczesne metody uniwersyteckiego nauczania bibliologii i kształcenia ludzi książki, opierające się na pragmatyzmie metody oglądowej, tj. okazywaniu omawianych obiektów. I nadal pozostają aktualne ówczesne metody sprawdzania przyswajanej wiedzy bibliologicznej, uwzględniające w pytaniach egzaminacyjnych te same etapy życia i funkcjonowania książki, tj. historyczną wiedzę na temat języków i pism, drukarstwa, bibliotekarstwa i bibliografii. Wypada więc z naciskiem powtórzyć słowa profesora Estreichera st., byłego studenta profesora Muczkowskiego, którymi zakończył swoje przemówienie z 22 III 1865 r., inaugurujące jego wykłady w Szkole Głównej w Warszawie: „[...] Obok więc prac innych naukowych nie zaniedbujmy studiów bibliograficznych, nie lękajmy się ich, a przekonamy się, że bibliografia nie jest to pole jałowe i suche dla tych, którzy na przeszłość patrzą jak na ogniwo z teraźniejszością [...]"70. Znaczenie i wartość działalności dydaktycznej J. Muczkowskiego są dla bibliologicznego dziedzictwa w Polsce bezsporne. 
Fot. 2. „Pytania z bibliografii z drugiego półrocza”. Źródło: BJ, rps nr 5160, t. 1: Dyplomatyka, k. 194r.

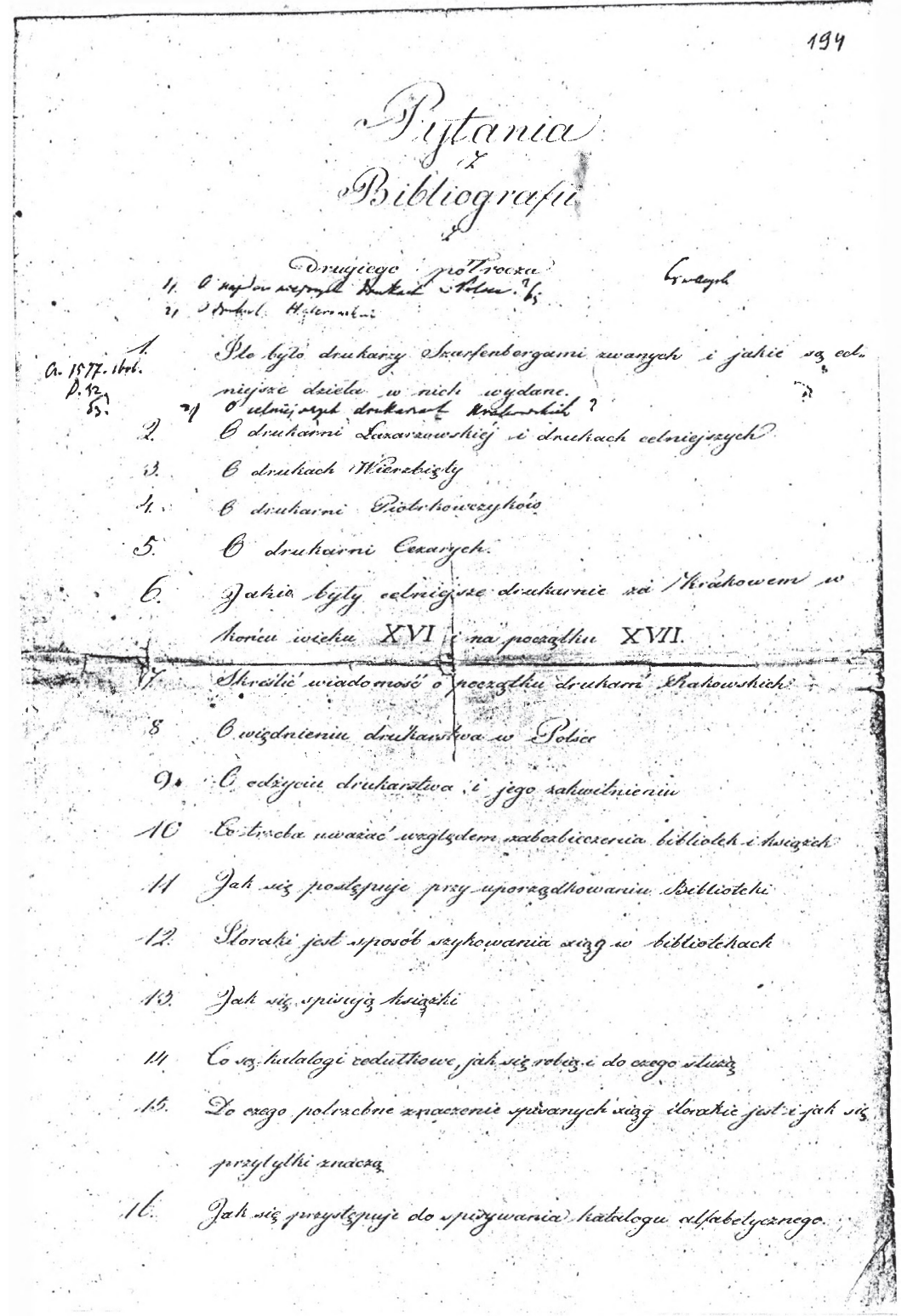


Fot. 3. Sześć numerowanych pytań egzaminacyjnych, [Inc.:] „1. Co jest bibliografia i jak się dzieli?” Źródło: BJ, rps nr 5175, Różne materiały J. Muczkowskiego, k. 148r.

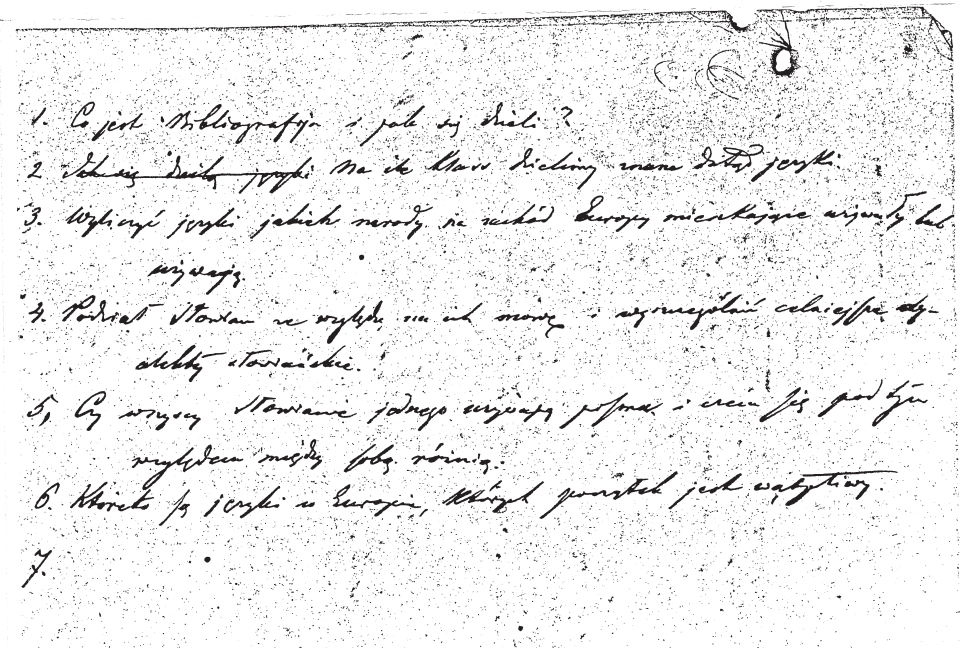

Fot. 4. Siedem nienumerowanych pytań egzaminacyjnych, [Inc.:] „, Wspomnieć celniejszych drukarzy od w. XVI.”. Źródło: BJ, rps nr 5790, t. 3: Biblioteki i bibliotekarstwo, k. 127r.

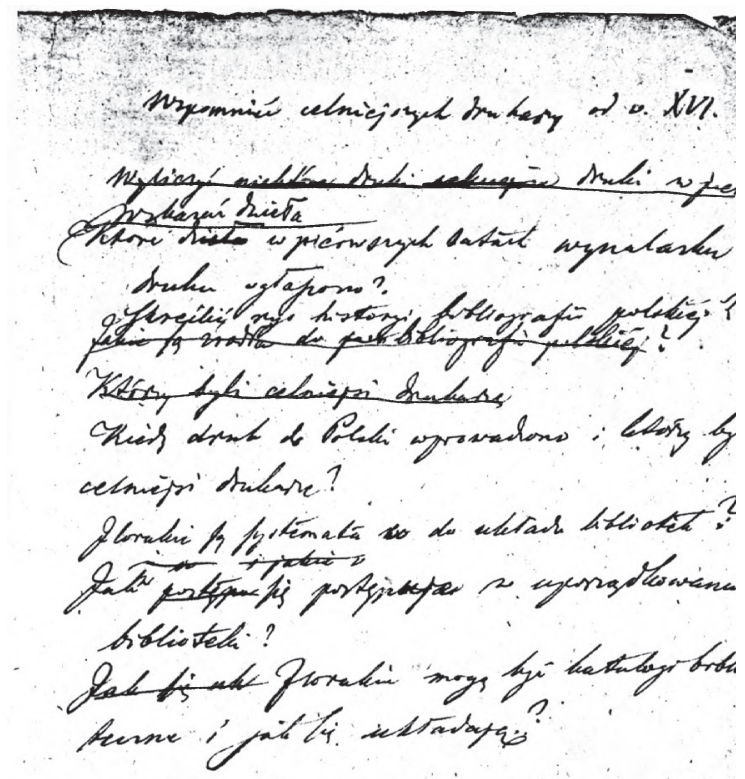




\section{Bibliografia}

\section{Rękopisy}

Kraków, Biblioteka Jagiellońska

rps 5154 - Kurs bibliografii przez J. S. Bandtkie, profesora w Akademii Krakowskiej dnia 18 paźdz[iernika] [1]815 rozpoczęty; notatki J. Muczkowskiego.

rps 5160 - t. 1: Dyplomatyka, t. 2: Notatki do dyplomatyki [i rękopisoznawstwa]; notatki

J. Muczkowskiego oraz wyciągi z dzieł innych autorów, 2 t.

rps 5175 - Różne materiały J. Muczkowskiego.

rps 5696 - Bibliografia; niedatowane notatki z wykładów J. Muczkowskiego spisane przez W. Tymienieckiego.

rps 5790 - t. 1: Bibliografia, t. 2: Drukarstwo, t. 3: Biblioteki i bibliotekarstwo; notatki J. Muczkowskiego w niedatowanej fazie kompletowania i porządkowania przez

S. Muczkowskiego, planującego ich publikację.

rps 6309 (dawn. sygn. Fol. 96) - Wykłady bibliografii ś. p. Józefa Muczkowskiego profesora i bibliotekarza Uniw[ersytetu] Jag[iellońskiego] miewane w latach ........ wydat Stefan Muczko[wski] Kraków 1871 r.; przeważnie autograf S. Muczkowskiego.

rps Przyb. 191-251/71 - Kurs bibliografii, wyłożony przez ś. p. Józefa Muczkowskiego wr. 1846-47; notatki spisane przez F. Karlińskiego. Wrocław, Biblioteka Zakładu Narodowego im. Ossolińskich

rps 6122/I - Bibliografia i wiadomość o naukach dajacych poznać źródta historyczne. Wykłady w pótroczu zimowym roku 1851/2 na Uniwersytecie Jagiellońskim dra Józefa Muczkowskiego, bibliotekarza i profesora na tymże Uniwersytecie w Krakowie [spisał] J. Łoziński.

rps 6124/I - Muczkowskiego Józefa prof. przy Uniwersytecie Jagiellońskim w Krakowie odczyty o bibliografii, Z. 1-[3], 1850; notatki J. Łozińskiego.

rps 6515/II - Muczkowski J., Listy i materiały; list J. Muczkowskiego do J. Łozińskiego z 14 czerwca 1853 r., k. 315 r.

Publikacje

Barycz H., Schyłek katedry bibliografii na Uniwersytecie Jagiellońskim i niedoszła profesura tego przedmiotu Karola Estreichera, [w:] Ksiega pamiątkowa ku czci Karola Estreichera (1827-1908). Studia i rozprawy, [red. R. Hennel], Kraków 1964, s. 31-43. Budik P.A., Vorbereitungsstudien für den angehender Bibliothekar, Wien 1834.

Budik P.A., Vorschule für bibliothekarisches Geschäftsleben, München 1848.

Chmielowski P., Jerzy Samuel Bandtkie.*1768†1835, [w:] Album biograficzne zastuzonych Polaków i Polek wieku XIX. T.1, Warszawa 1901, s. 414-416.

Ebert F.A., Die Bildung des Bibliothekars, $2^{\text {te }}$ umgearb. Ausgabe, Leipzig 1820.

Ebert F.A., Zur Handschriftenkunde. Erstes Bändchen, Leipzig 1825.

Au.K. [K. Estreicher st.], Józef Muczkowski, „Dziennik Literacki” 1858, t. 2, nr 97, s. 790-792. 
Estreicher K. [st.], Józef Muczkowski, *1795†1858, [w:] Album biograficzne zasłużonych Polaków i Polek wieku XIX. T. 2, Warszawa 1903, s. 414-418.

Estreicher K. [st.], Memoriat w obronie katedry bibliografii, wyd. K.Ś. [Ksawery Świerkowski], „Przegląd Biblioteczny” 1928, R. 2, z. 1, s. 49-52.

Estreicher K. [st.], O bibliografii. Przemówienie w Szkole Głównej w Warszawie, miane dnia 22 marca 1865 r., przy rozpoczęciu wykładu tej umiejętności, Warszawa 1865.

Estreicher K. [st.], Z listów. Cz. 2, [wyd.] J. Grzybowska, „Biuletyn Biblioteki Jagiellońskiej” 1961, R. 13, nr 1, s. 5-38.

Friedrich J.Ch., Kritische Erörterungen zum Übereinstimmenden Ordnen und Verzeichnen öffentlicher Bibliotheken, Leipzig 1835.

Fulara G., Malicka E., Spuścizna po Aleksandrze Birkenmajerze w Bibliotece Jagiellońskiej, „Roczniki Biblioteczne” 2007, R. 51, s. 43-59.

Heeren A.H.L., Christian Gottlob Heyne. Biographisch dargestellt, Göttingen 1813.

Helcel A.Z., Jerzy Samuel Bandtkie w stosunku do spoteczności i literatury polskiej. Przyczynek naukowy do dziejów literatury ojczystej, Kraków 1836.

Krzywicki J., Katedra bibliografii. Profesor Karol Estreicher, [w:] Szkoła Główna Warszawska (1862-1869). T. 1: Wydziat Filologiczno-Historyczny, Kraków 1900, s. 251-258.

Lelewel J., Bibliograficznych ksiag dwoje, w których rozebrane i pomnożone zostały dwa dzieła Jerzego Samuela Bandtke Historia drukarń krakowskich tudzież Historia Biblioteki Uniw. Jagiell. w Krakowie a przydany katalog inkunabułów polskich. T. 1-2, Wilno 1823-1826.

Lelewel J., Dzieje bibliotek do Dziennika Warszawskiego..., Warszawa 1828.

Lelewel J., Nauki dajace poznawać źrzódta [sic!] historyczne, Wilno 1822.

Lewicki K., Jerzy Samuel Bandtkie, profesor bibliografii Uniwersytetu Jagiellońskiego, 1811-1835, „Roczniki Biblioteczne” 1972, R. 16, z. 1/2, s. 113-138.

Molbech Ch., Über Bibliothekswissenschaft, oder Einrichtung und Verwaltung öffentlicher Bibliotheken. Nach der 2. Ausgabe des dänischen Originals übersetzt von H. Ratjen, Leipzig 1833.

Muczkowski J., Dwie kaplice Jagiellońskie w katedrze krakowskiej, Kraków 1859; odb.: Dwie kaplice Jagiellońskie w Krakowie oraz najdawniejsze wizerunki Jagietty i Jadwigi, ,Rocznik Towarzystwa Naukowego Krakowskiego” 1858, t. 25.

Namur J.P., Histoire des bibliothèques publiques de la Belgique. T. 1-3, Bruxelles 1840-1842: T. 1: Histoire des bibliothèques publiques de Bruxelles, Bruxelles 1840; T. 2: Histoire de la Bibliothèque Publique de Louvain, Bruxelles at Leipzig 1841; T. 3: Histoire de la Bibliothèque Publique de Liége, Bruxelles at Leipzig 1842.

Namur J.P., Manuel du bibliothécaire, accompagné de notes critiques, historiques et littéraires, Bruxelles 1834.

Olszewicz W., Pamiętnik bibliotekarski Józefa Łozińskiego, „Roczniki Biblioteczne” 1959, R. 3, z. 1/2, s. 257-280.

Schrettinger M., Handbuch der Bibliothekswissenschaft, besonders zum Gebrauche der Nicht-Bibliothekare, welche ihre Privatbüchersammlungen selbst einrichten wollen, Wien 1834. 
Schrettinger M., Versuch eines vollständigen Lehrbuches der Bibliothekswissenschaft. I.-III. Hefte, München 1808-1810.

Vogel E.G., Literatur früherer und noch bestehender europäischer öffentlicher und Corporations-Bibliotheken, Leipzig 1840.

Vrtel-Wierczyński S., Bibliografia, jej istota, przedmiot i początki, Lwów 1923.

Vrtel-Wierczyński S., Teoria bibliografii w zarysie, Wrocław 1951.

Wilken F., Geschichte der Königlichen Bibliothek zu Berlin, Berlin 1828. 